\title{
Facing up to Constantine: Reassessing the Stonegate Monumental Head from York
}

\author{
By MILES RUSSELL
}

\begin{abstract}
A damaged and badly weathered stone head, discovered prior to 1823 in York, and interpreted as an early portrait of the emperor Constantine I, is here re-examined and identified as a modified image of an earlier, deified emperor, almost certainly Hadrian. A re-analysis of the image as it survives today further suggests that the recarving, into a likeness of Constantine, occurred after A.D. 312 and not, as widely believed, at the moment of Constantine's proclamation as emperor in York in A.D. 306.
\end{abstract}

Keywords: Constantine; Hadrian; sculpture; imperial portraiture; identity realignment; York

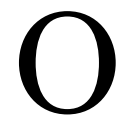
$\mathrm{f}$ all the pieces of statuary recovered from Roman Britain, arguably one of the most famous is the monumental, battered head of an adult male on display in the Yorkshire Museum. ${ }^{1}$ The portrait was first identified as a probable likeness of Constantine I (A.D. 306-37) in 1944 by Ian Richmond (see below), ${ }^{2}$ and this has since become the accepted interpretation. Little is really known about the artefact, however, as the precise circumstances surrounding its original context and discovery were not recorded. Although the identity of the image seems secure, there is one aspect of the sculpture that has escaped discussion, for the face that we see today would appear to be a secondary modification: a piece of fourth-century identity realignment, reshaping and changing a much earlier portrait. The identification of two discrete periods of portrait manufacture has a significant impact on the overall interpretation, importance and date of the head, all of which are considered here for the first time.

\section{DESCRIPTION}

The head was presented to the museum of the Yorkshire Philosophical Society in 1823 by James Atkinson, a York surgeon, ${ }^{3}$ who had acquired the artefact following the excavation of 'a drain in

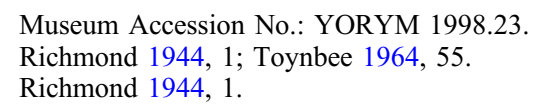


Stonegate'. ${ }^{4}$ Stonegate is a medieval street that lies directly over the via praetoria of the Roman legionary fortress and it is possible, therefore, that the statue, of which the head formed part, originally stood within the area of the principia, or headquarters building; an appropriate place for such a monumental representation to have been placed. ${ }^{5}$

The portrait is twice life-size (FIG. 1a-d), measuring $0.42 \mathrm{~m}$ in height, $0.27 \mathrm{~m}$ in width and 0.3 $\mathrm{m}$ in depth and with a base diameter of $0.17 \mathrm{~m}$. The axis of the neck suggests that the face had originally been turned slightly to the left and down towards an audience below. Carved from marble, ${ }^{6}$ the piece was almost certainly part of a statue, the rest of the body, which may possibly have been manufactured from a different material, having been lost.

The nature of the carving suggests that the individual was wearing an ornate oak-leaf crown, the corona civica, fastened with a large bow at the back of the head. The crown is asymmetrically shaped with large, widely spaced, forward-facing leaves creating an overall distinctly foliage-sparse effect. The character's hair is moderately long across the nape of the neck and cut high above the ears, with no trace of sideburns evident. The slightly receding, short-cut fringe is also worn high, individual locks being combed forwards, from left to right across the forehead, below the line of the wreath. Above the oak-leaf crown the head is smooth, with no attempt being made to depict individual strands of hair, an effect which would, in any case, have been invisible to an audience below.

Overall, the coiffure is weakly depicted and distinctly lopsided. The unrealistic curls defining the fringe across the left-side of the head, curve severely from the temples to high above the left ear, individual strands lying flat and lifeless upon the contours of the skull. In contrast, the hair on the right side of the head is more clearly defined, deeply cut individual curls breaking free from the oak-leaf crown to the right ear while, across the forehead, the fringe falls to within touching distance of the right brow. Hair on the nape of the neck is less severe than at the front, deeply incised individual locks flowing below, and running parallel with, the line of the oak-leaf crown. The rough nature of the neck below the hairline suggests that the coiffure may originally have been more extensive, descending to well below the line of the ears. The neck itself is broad and excessively muscular when compared to the face.

Facial features have been badly affected by weathering across the right side and forehead, the nose especially, the middle and lower thirds to the nasal tip being lost leaving only the deep-set nostrils and slight traces of the upper nasolabial fold. It is unclear whether this erosion occurred while the statue was still standing, and exposed to the elements, or whether it represents damage sustained following its toppling and subsequent burial. With so little of the nose surviving, it is difficult to make any useful comment concerning the original shape and form, although Richmond enthusiastically described the profile as being 'Grecian' with 'just a trace of aquilinity'. ${ }^{7}$ The forehead is smooth and, despite the rather 'fleshy' nature of the face, the cheekbones are quite pronounced. The cheeks, chin and upper lip are clean-shaven; the chin itself is broad and, given the overall size of the head, appears to display a tendency 'towards roundness'. 8

When viewed in profile, the whole plane of the face is unnaturally flat, the chin and brow extending only a very short distance from the plane of the neck. Furthermore, although the

ibid.

ibid., 5; RCHME 1962, 112; Toynbee 1962, 125; Tufi 1983, 23; Bidwell 2006, 35.

Originally interpreted as being of Magnesian Limestone, an important building material which outcrops in the north of England from Teeside to Nottingham, the stone has since been re-identified as a coarse crystalline marble, of possible Italian origin: Tufi 1983, 23; Hartley et al. 2006, 120.

Richmond 1944, 2.

8 Hartley et al. 2006, 120. 

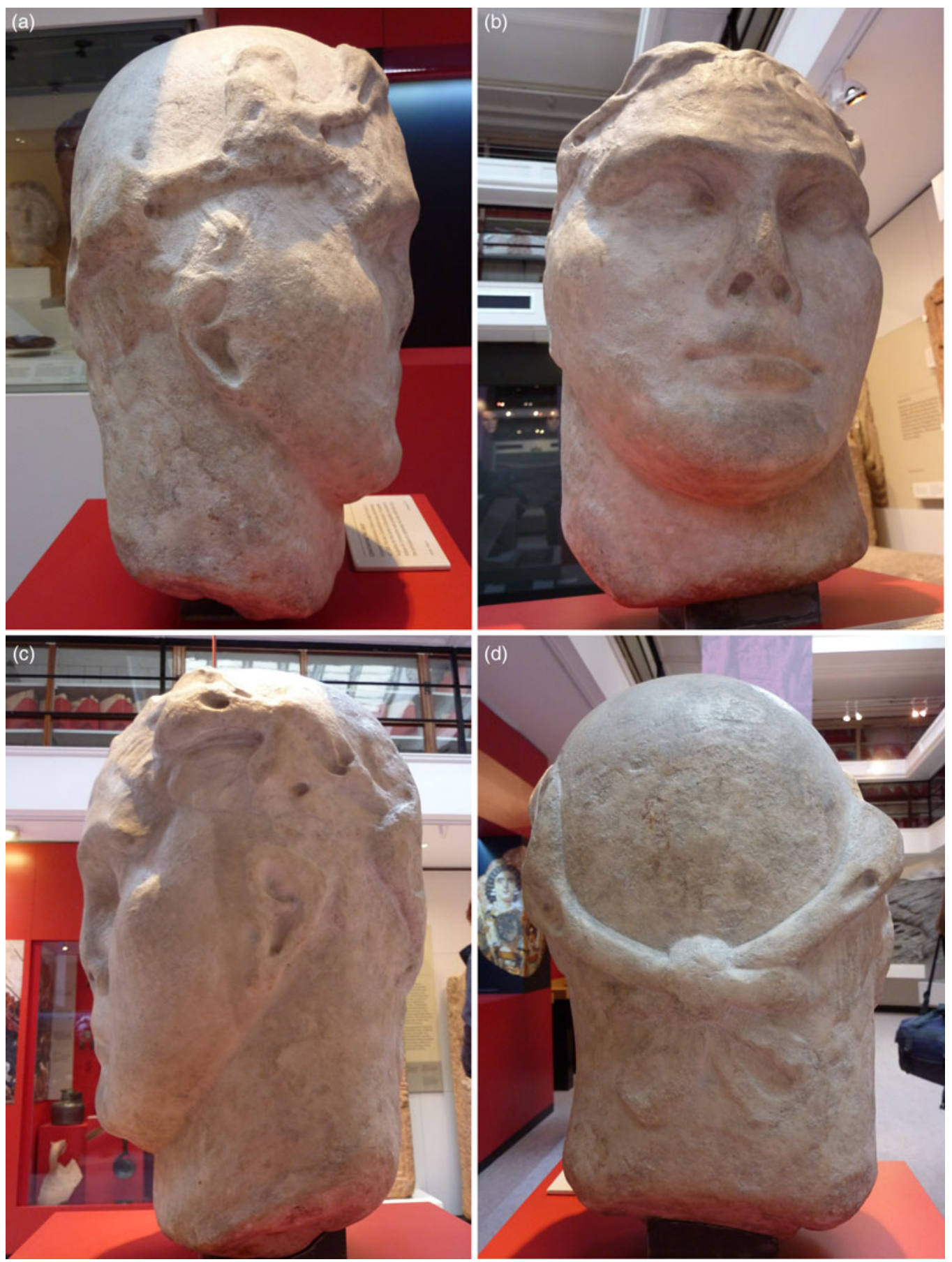

FIG. 1. The Stonegate head, York, YORYM: 1998.23: (a) right profile; (b) front view; (c) left profile; (d) back. (Photos: M. Russell; ; York Museums Trust, Yorkshire Museum) 
head itself is of monumental scale, the deep-set eyes are represented life-size, giving the portrait a curiously unrealistic feel. The low set brows are heavy and slightly arched, lifting with a unnaturalistic crow's foot effect at the outermost edges. An attempt to create the illusion of life and depth has been made within the eyes, the inner corners and pupils of which have been drilled while the irises are lightly incised.

Like the eyes, the mouth is small, being depicted almost life-size in contrast to the more dramatic size of the head. As with the nose, the lips are damaged and appear slightly drooping at the corners, which have been drilled, creating an overall effect that Richmond described as 'pouting'. ${ }^{9}$ The ears, which are rather too large in proportion to the face, are set close to the line of the head. The irregular nature of the upper lobes makes them appear fleshy. In relation to the face, the ears are positioned low, the right ear, in particular, lying well below the line of the right eye. This unnatural arrangement is almost unnoticeable when viewing the portrait from the front and below.

\section{IDENTIFICATION}

Ian Richmond was the first to appreciate the potential significance of the Stonegate head. Rescuing the artefact 'from its limbo in the basement of the Yorkshire Museum' ${ }^{10}$ he had it cleaned and photographed, confidently identifying it as a replica of the emperor Constantine I. ${ }^{11}$

There can be little doubt that the head, at least in its final form, was intended to represent Constantine 'the Great' (A.D. 306-37). First, as a monumental, twice life-size portrait in marble, the piece cannot be anything other than imperial, the scale and quality both excluding the possibility that this was the simple depiction of a governor, regional administrator, general or civic dignitary. Secondly, its beardless appearance, as we see it today, furthermore excludes a comparatively large number of imperial candidates. The clean-shaven look, although de rigeur among the Roman elite of the earlier first century, fell from favour after Hadrian came to power in A.D. 117, emperors thereafter appearing with either well-groomed facial hair or short stubble. It was Constantine, at the start of the fourth century, who reset imperial fashion, electing to appear in official portraiture with a smooth countenance. ${ }^{12}$ No doubt this was, at least in part, an attempt to evoke the Augustan image of the youthful, clean-shaven princeps with a short, almost casually combed, cap of hair. Together, the Julio-Claudian coiffure and shaved cheeks apparent in the York replica, when combined with the 'broad, geometric treatment of the facial planes' and drilled eyes, both distinctive features in late antique art (FIG. 2a and b), suggest that this is an image of Constantine, or perhaps one of his immediate heirs. ${ }^{13}$

Richmond 1944, 2.

Toynbee 1962, 125; 1964, 55.

Richmond 1944, 5.

L'Orange 1933, 48; Harrison 1967, 95; Wright 1987, 493; Kleiner 1992, 434-5.

Richmond 1944, 3. 

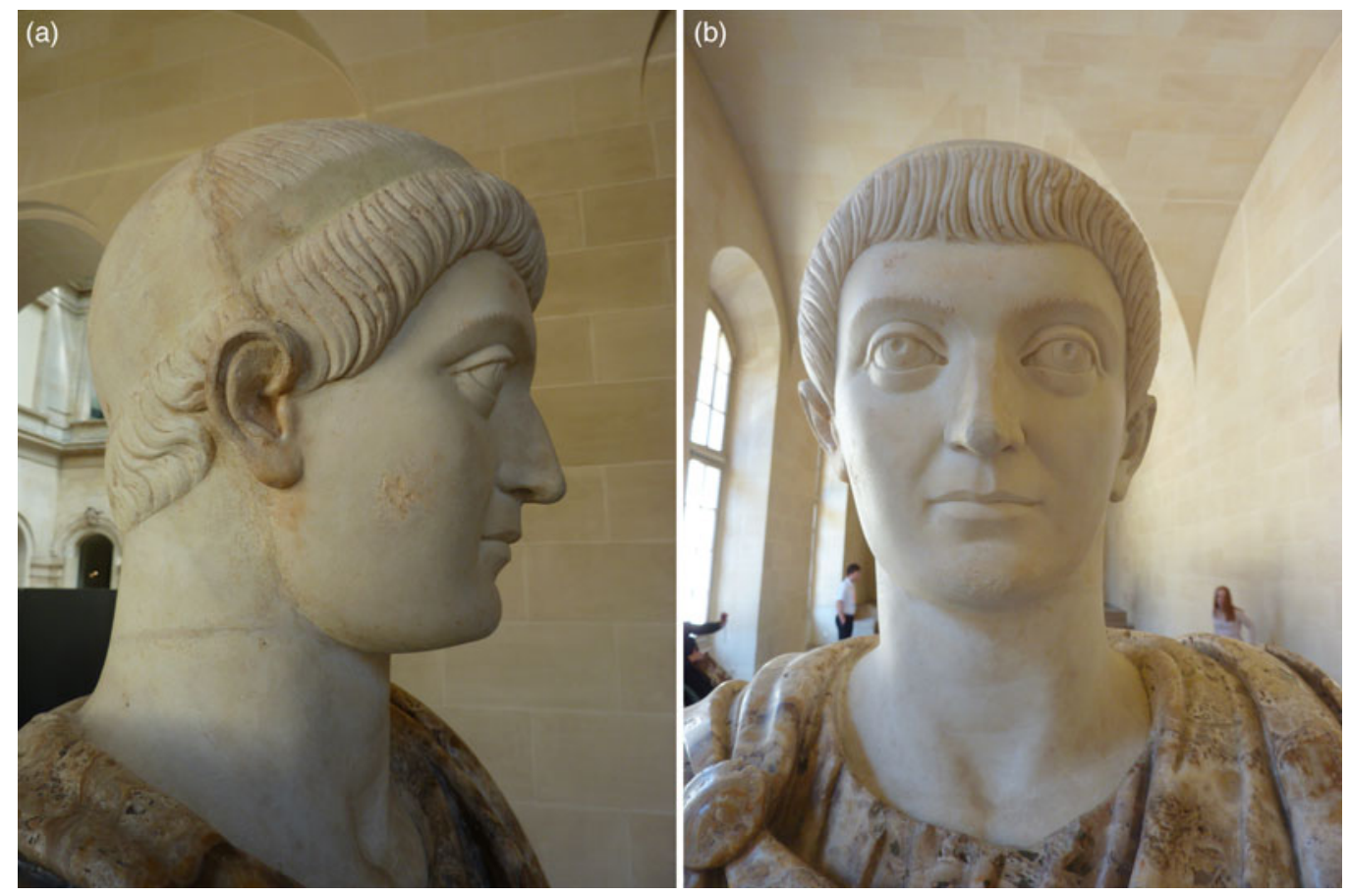

FIG. 2. Portrait of either Constantine I or, more likely, his son Constans, as an idealised clean-shaven youth, with large eyes and arched brows, preserved in the Musée du Louvre, Paris, MA 1021: (a) right profile; (b) front view. (Photos: M. Russell; (C) Musée du Louvre)

The ornate oak-leaf crown, or corona civica, that adorns the Stonegate head was an item of head attire the wearing of which, by the first century, had become an imperial prerogative. ${ }^{14}$ Although largely abandoned in official portraiture at the beginning of the second century, the crown clearly appealed to Constantine, whose 'archaistic tendencies' preferred to borrow from the first-century stylings of the Julio-Claudian dynasty rather than from the more hirsute, radiate-crown wearing 'soldier emperors' of the third century. ${ }^{15}$ So closely was the oak-leaf crown associated with the reign of Constantine that it seems to have fallen out of favour at his passing, his heirs, on coin and in the round, preferring more ornate forms of imperial diadem.

Constantine was 34 years old in A.D. 306, when he was first acclaimed emperor by the soldiery of York following the death of his father, Constantius Chlorus. Richmond felt that, if the Stonegate head was intended as a representation of Constantine at the moment of his unauthorised promotion, there was a very strong claim that the artefact should take 'precedence in date among the known portrait heads of the most famous of later Roman emperors'. ${ }^{16}$

\section{DISCUSSION}

Despite the relative certainty of Richmond's identification, there remain significant concerns with regard to the nature and form of the Stonegate head. The most serious issue is that the clean-shaven

14 Hiesinger 1975, 115.

15 L'Orange 1933, 58; Richmond 1944, 3.

16 Richmond 1944, 5. 
imperial face clearly does not fit the overall proportions of the head. The image that we see today, therefore, may not have been the original intended identity of the sculpture, the life-size portrait of the 'youthful' emperor Constantine having been carved into, effectively overwriting, a much earlier monumental likeness.

Several elements demonstrate and confirm that Constantine's portrait has been cut directly over, almost entirely removing, the facial features of another. First, as has already been noted, the sensory organs of the face are depicted to scale, while the head, hair-stylings and neck all clearly indicate that the original portrait was at least twice life-size. Furthermore, when viewed from the side, it is apparent that the features of the head are foreshortened; flattened and unrealistic profiles such as this being characteristic of recarved portraits where a secondary sculptor has attempted to remove the distinctive physiognomy and personality of a primary-phase character. ${ }^{17}$

The eyes, arguably the most important and recognisable part of any likeness, were usually the first aspect of sculptural identity to be realigned, the originals being removed and reworked prior to any other aspect of facial modification. Hence, the eyes in the majority of secondary-phase images usually appear more deep set, being placed beneath prominently overhanging brows, than in those in sculptures that have otherwise escaped alteration. In some instances, the deep-cut erasure of the original eyes and reworking of the sockets necessitated the creation of enlarged crow's feet at the corners of the new setting in order that the 'uneven transition' between socket and cheek could be more effectively concealed. Such an effect has clearly been employed in the Stonegate head where the low and heavy eyebrows lift in a distinctly unnatural way at their outermost edges.

Further clues to the nature of secondary working are visible on the ears of the York portrait which do not sit in their correct anatomical position, lying low on both sides of the head. This is an effect that is not readily apparent when the portrait is viewed from the front, as in most modern photographic reproductions of the artefact, or below, as a Roman audience would have perceived it, but is something which is immediately clear when seen in profile. Ears were a major problem for sculptors when modifying the identity of stone portraits and it is evident that, where possible, they preferred to avoid any form of significant alteration. Failure to modify ears during identity realignment occasionally had the unintended side effect of preserving areas of the original coiffure, especially where it framed or touched the primary setting. ${ }^{18}$ In the case of the Stonegate head, the longer, livelier and more deeply cut individual curls of hair that fall towards the right ear indicate a major disparity in styling, away from the shorter, stiffer and less well incised coiffure across the forehead. The rough and irregular shape of the neck, below the hairline, at the back of the Stonegate portrait further suggests that the original image possessed a longer-flowing mane and that attempts to mask this in the subsequent reworking were only marginally successful.

The cutting back of the earlier hairstyle, with its undoubtedly more voluminous locks, resulted in a curiously unnatural, almost 'pointed' shape to the upper part of head, an effect that is magnified by the absence of hair across the top of the portrait and the almost half-hearted creation of incised locks along the forehead, ultimately intended to create the impression of a first-century Julio-Claudian-style cut. This artificial form of baldness, generated no doubt during the energetic removal of the original curls, would have been effectively disguised by the inclusion of the oak-leaf crown which, unless it was part of the earlier, primary image, was probably fashioned from the distinctive hair-styling of the original sitter.

The fact that the face we see today was recut from an earlier image should not perhaps be surprising, for the portraits of Constantine I that survive, including famous examples preserved in the Musei Capitolini in Rome and the Ny Carlsberg Glyptotek in Copenhagen, all appear to

Prusac 2011, 85 .

18 ibid., 86. 
have been secondary recarvings, ${ }^{19}$ the majority being worked from images that were originally over life-size (see below). Constantine seems to have utilised and exploited earlier public sculptural forms to a degree not seen either before or after his reign. ${ }^{20}$ From an economic perspective, recycling made sense since, by the start of the fourth century, the Roman State no longer possessed either the quantity of raw material nor the funds required for any significant new work in marble, the infrastructure of procurement and transportation having long been in decline. $^{21}$ Constantine presumably felt that there was no need to extract and work new or established marble sources when a relatively large amount of sculpture, depicting earlier emperors, already existed and could easily be expropriated. ${ }^{22}$ The widespread reuse of earlier portraiture could also be a way for Constantine to successfully and publicly compare himself with the 'good' emperors of the past while simultaneously indicating to the wider population the arrival of a dynamic new order. ${ }^{23}$

The monumental size of the Stonegate head, together with the use of imported marble, suggests that the primary statue was originally the post-mortem image of a deified princeps, rather than a reigning emperor, or of a deity (perhaps Jupiter or Mars) or demigod (such as Hercules). In the early Roman period, there were clear proscriptions against the conversion of deity portraits into those of mere mortals, ${ }^{24}$ but by the third and fourth century, such attitudes appear to have become more relaxed, ${ }^{25}$ emperors being only too happy to be sculpted in the guise, pose and with the accoutrements of particular gods. The most popular figure, when considering the appropriation of the divine image, was Hercules, partly because he was a demigod, and son of Jupiter, but also because of his associations with strength, power and potency. Constantine, despite his later Christian leanings, was no different in this respect and there is at least one extant image of him, from Chania in Crete, which appears to have been recut from an earlier image of Hercules. ${ }^{26}$

We are perhaps on firmer ground when it comes to the fourth-century reuse of imperial portraiture since Constantine is known to have actively sought out and recycled the sculptured material of his illustrious, and sometimes less well-regarded, predecessors. ${ }^{27}$ Within the surviving images of Constantine, portraits of first- and early second-century emperors have been identified, ${ }^{28}$ where key elements of physiognomy and coiffure have been retained from the original replica. It has, in fact, been suggested that certain identifiable features from earlier, primary portraits were deliberately kept so that Constantine could be favourably compared and associated with 'good' emperors such as Trajan or Hadrian. ${ }^{29}$

Probably the most famous piece of identity realignment to survive from the ancient world, creating an image of Constantine from a pre-existing portrait, is the so-called 'colossus' in the courtyard of the Palazzo dei Conservatori in Rome (FIG. 3a and b). The head as it appears today has clearly been recut, traces of the primary portrait surviving in the shape and position of the ears and the thick locks of hair that frame them, both of which have been left untouched during the reworking process. ${ }^{30}$ When viewed in profile, it is evident that the enlarged eyes of the colossus have been cut deep into the head in such a way as to erase all trace of the primary

19 ibid., 64.

20 ibid., 147-8; Calomino 2016, 211.

21 Blanck 1969, 96-105; Kinney 1997, 134; Prusac 2011, 68.

22 Prusac 2011, 68, 147, pls 52-8.

23 Calomino 2016, 211.

24 Prusac 2011, 110.

25 Wrede 1981; Alexandridis 2004, 54-5; Galinsky 2008, 3.

26 Blanck 1969, 55-6; Prusac 2011, 111, 147-8.

27 Calomino 2016, 211.

28 Harrison 1967, 95; Prusac 2011, 147-8.

29 Harrison 1967, 95; Evers 1991, 255; Prusac 2011, 64.

30 Varner 2004, 217-18, 287; Prusac 2011, 70. 
eyebrows, eyeballs and sockets. ${ }^{31}$ The original identity of the colossus has been much debated ${ }^{32}$ although Evers ${ }^{33}$ and Prusac ${ }^{34}$ have made convincing arguments for it having been Hadrian, the volume of his beard providing sufficient raw material, even when cut back, for Constantine's strong jaw and chin.
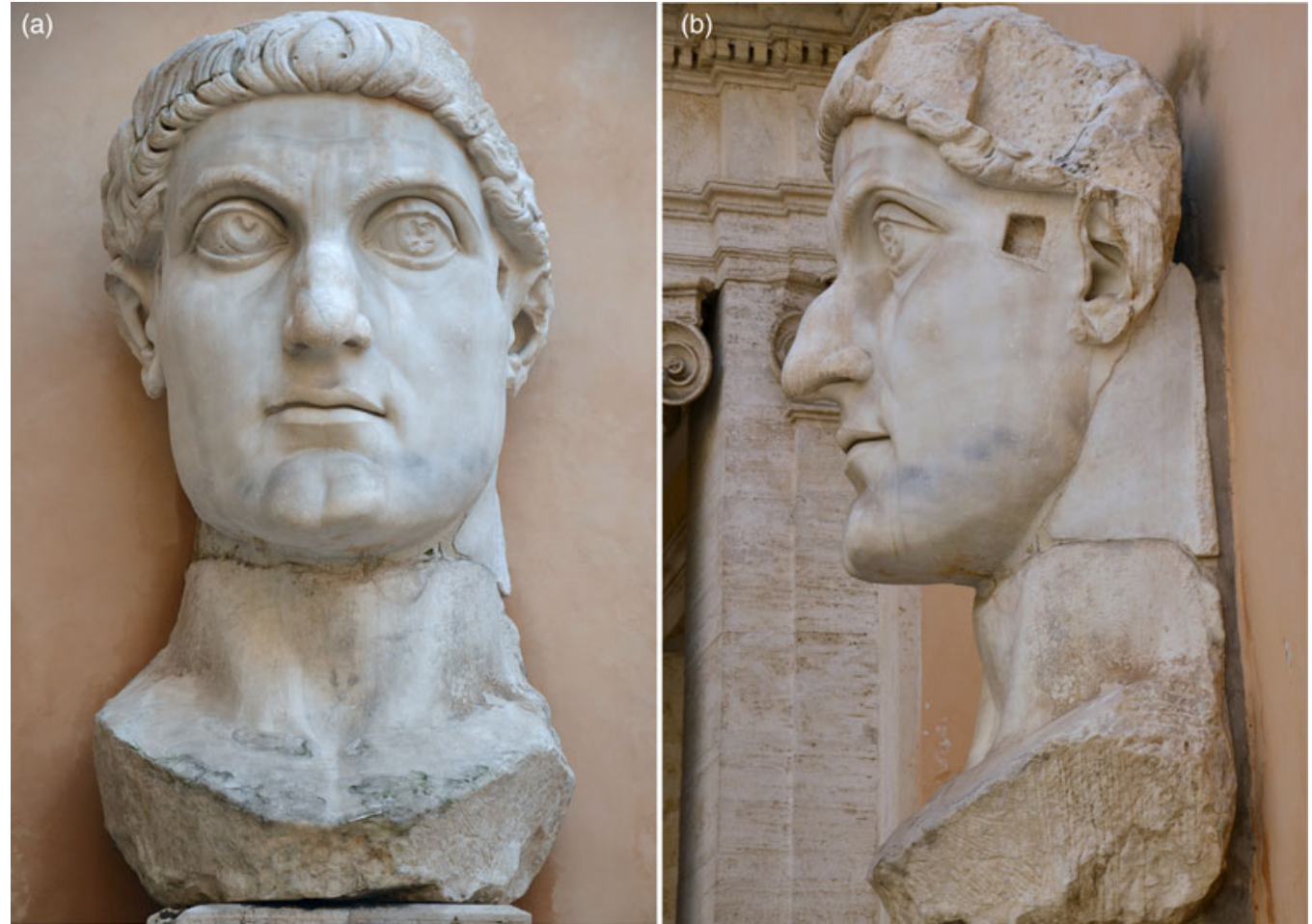

FIG. 3. The 'Colossus of Constantine', probably reworked from an original monumental portrait of Hadrian, in the Palazzo dei Conservatori of the Musei Capitolini, Rome: (a) front view; (b) left profile. (Photos: C. Raddato; (C) Musei Capitolini)

With regard to the speculative primary identity of the Stonegate head, if it was, as seems apparent from its monumental scale, the post-mortem likeness of a deified princeps, a number of candidates present themselves, apotheosis having been granted to only a small number of emperors with any clear association with Britannia. From the Julio-Claudian dynasty, it is possible, although perhaps unlikely, that the image originally depicted Augustus, first emperor of Rome (27 B.C.-A.D. 14), or Claudius (A.D. 41-54), the conqueror of Britain, both having died some significant time before either the establishment of the full province or the building of the fortress of Eboracum.

Prusac 2011, 71

e.g. Harrison 1967, 94; Varner 2004, 287.

Evers 1991.

Prusac 2011, 70-1. 
From the Flavian dynasty, a case could be put forward for either Vespasian (A.D. 69-79) or his son Titus (A.D. 79-81), as both received divine honours after death. The total conquest of Britain was a 'pet project' of the Flavian family, Vespasian initiating the push north in A.D. 77, the last great battle, cementing Roman victory, being fought at Mons Graupius in around A.D. 83 during the reign of his youngest son, Domitian (A.D. 81-96). Although Domitian was to celebrate the culmination of the war on coin and in stone monuments, one of which was almost certainly placed in what is now southern Scotland, ${ }^{35}$ he was a ruler who ultimately proved unpopular with the Senate and, following his assassination in A.D. 96, his image underwent severe memory sanctions making it unlikely that a larger than life, post-mortem statue of him would have been created. Domitian's predecessor, his elder brother Titus, however, may have been celebrated in stone, for in the early second century the Roman biographer Suetonius noted that 'numerous statues and busts' of Titus could in his day be seen across Britain. ${ }^{36}$ Unfortunately, no statues survive today, although it is possible that a large likeness of this particularly 'fleshy' emperor could have survived into the early fourth century to be refashioned into an image of Constantine.

A better candidate for the primary phase of the Stonegate head may be the emperor Trajan (A.D. 98-117). Although Trajan appears to have had very little real political or military interest in Britain, as a prominent and much-celebrated emperor of the later first and early second century we should not be surprised to find images of him set in key locales across the province. Indeed, a twice life-size portrait of the deified optimus princeps has been identified from Bosham in West Sussex. ${ }^{37}$ This particular image, also in marble, probably formed part of a freestanding statue of the emperor erected by Hadrian, his immediate successor, during a visit to Britain in A.D. $122^{38}$ when he set the limits to the province and initiated a major urban rebuilding programme. The legionary base of Eboracum was also undergoing significant modification during the early second century and it is likely, given Hadrian's evident interest in the northern frontier, that he personally oversaw aspects of the fortress rebuild. The erection of a second monumental image of Trajan at this time within the confines of the province's northernmost legionary fortress does not therefore seem impossible.

Hadrian himself (A.D. 117-38) could also have been posthumously commemorated at York given that his heir, Antoninus Pius (A.D. 138-61), was later keen to both honour his predecessor and further modify the British frontier. Under Hadrian, the VI Victrix legion had taken up occupancy of Eboracum, replacing the earlier IX Hispana, and the new garrison may have felt especially compelled to erect a monumental image of the recently deified princeps. A post-mortem representation of Antoninus Pius is also a possibility, although the uncertain nature of the frontier during his reign, combined with the widespread military instability that followed immediately thereafter, means that it is perhaps unlikely that he would have been so commemorated by Marcus Aurelius (A.D. 161-80), his successor. Aurelius himself could have been honoured with a statue by his son and heir Commodus (A.D. 180-92), who, under the governorship of Ulpius Marcellus, won a series of victories against the British tribes commemorated on official coins in A.D. $184,{ }^{39}$ although it is unlikely to have been an image of Commodus himself as his image underwent significant posthumous memory sanctions following his assassination.

Another plausible candidate for the identity of the Stonegate head is the emperor Septimius Severus (A.D. 193-211). Severus spent the last four years of his life in Britain, conducting an

37 Henig 1996, 83; Soffe and Henig 1999, 9; Russell and Manley 2015.

38 Russell and Manley 2015, 17.

39 Ireland 2008, 103-4 
ultimately fruitless campaign against the Caledonian tribes to the north of the frontier, finally dying in York. During the course of the war, the imperial family and their retainers may well have been housed in the praetorium of the legionary fortress, ${ }^{40}$ Eboracum at that time becoming the de facto political heart of the Empire. Despite the fact that the campaign was never fully resolved and was, after Severus' death, swiftly terminated, politically it was treated as a success by the State and was accordingly commemorated on the coinage as 'a great victory'. ${ }^{41}$ Given that Severus' sons were keen to promote the myth of a triumph, it is possible that the imperial propaganda machine extended to the creation of a monumental representation of the deified princeps in the place where he had lived and finally died.

We may get closer to the true identity of the primary portrait, given that so much of the early face has been reworked and removed, from the few surviving areas of the original coiffure that survives. It has already been observed that the portrait that predates the short, stiff haircut of Constantine possessed a style comprising long and more lively curls, a factor which probably influenced the form taken by the later oak-leaf crown. The irregular shape of the neck further seems to indicate that the primary portrait possessed a more free-flowing mane of hair which originally descended well below the line of the ears. Of the imperial identities proposed for the York portrait, only those of the second and early third century, from Hadrian to Septimius Severus, fit the style identified.

The image of Hadrian, first established when he became emperor in A.D. 117, aged 41, portrays him with a neatly trimmed moustache and full beard, possibly in an attempt to disguise a poor complexion or weak chin, but more probably to imitate the fashion of Greek poets, philosophers and statesmen. ${ }^{42}$ Rejecting the rather formal Julio-Claudian cap favoured throughout the first century, Hadrian preferred a head of thick, curly hair, combed in waves down the nape of the neck and from the crown to the forehead, where delicate curls were arranged in careful patterns. ${ }^{43}$ This distinctive style of beard and tousled hair set a trend which was imitated by his contemporaries and much copied thereafter, becoming ever more fancy and ornate. Following the demise of Septimius Severus, in A.D. 211, multi-layered corkscrew locks, long and complex beards and idealised facial features were replaced, in imperial portraiture, with close-cropped hair, short beards or stubble and ever more stern and serious expressions.

If we take the larger than life representation to indicate the portrait of a deified princeps, one whose hirsute image was both significant to Britain and likely to have survived posthumous denigration, then only the emperors Hadrian, Antoninus Pius, Marcus Aurelius and Septimius Severus appear as plausible candidates. The frontier policies of Antoninus, Aurelius and Severus could hardly be described as successful, although all three certainly claimed major British victories during their lifetimes. Hadrian, on the other hand, not only had significant connections to Britain, personally overseeing the regeneration of the province and the establishment of a permanent frontier network, but also to the VI Victrix legion, based in York; his candidacy for the primary statue, although not conclusively proven, would therefore appear compelling. The reuse of monumental Hadrianic portraits was, as we have seen, certainly a feature in the creation of Constantine's official image, the so-called 'colossus' in the courtyard of the Palazzo dei Conservatori in Rome being a prime example. ${ }^{44}$

The curious, foliage-sparse nature of the oak-leaf crown on the Stonegate head, is, as has already been noted, likely to have been as a direct result of it having been fashioned from the distinctive hairstyle of the primary portrait during identity realignment. Of the candidates

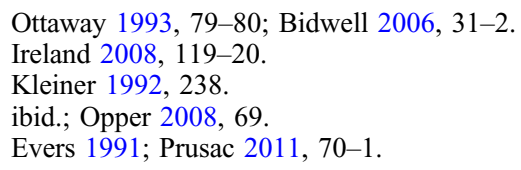


proposed for the original portrait, only the thickly curled, forward-combed coiffure of Hadrian appears to match the leaves as they appear on the head today (FIG. 4a and b), and indeed the longer and more deeply cut individual curls of hair of the earlier image that survive around the right ear.
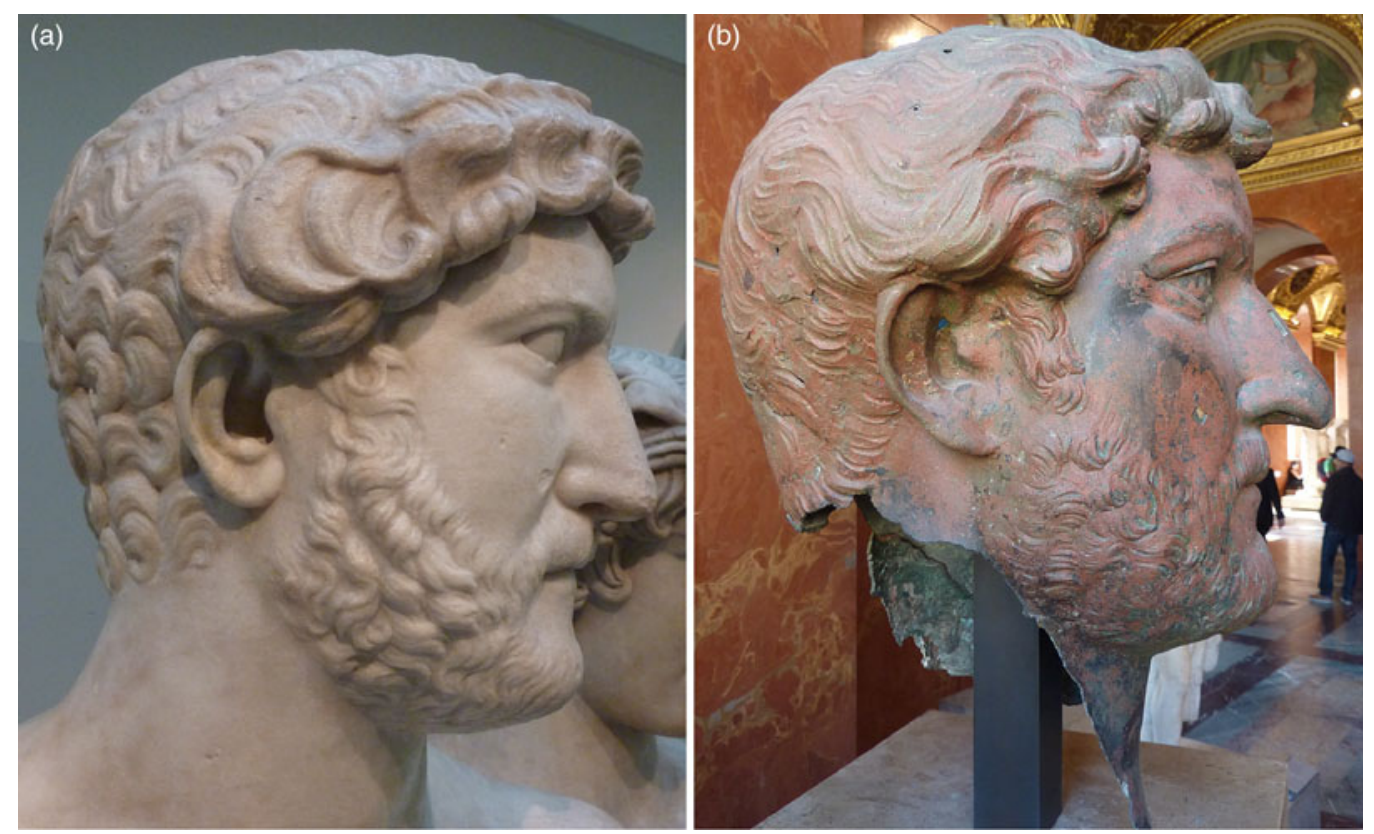

FIG. 4. Portraits of Hadrian: (a) right profile in marble preserved in the British Museum, London, GR 1805,0703.94; (b) right profile in bronze preserved in the Musée du Louvre, Paris, BR4547. (Photos: M. Russell; (C) British Museum and (C) Musée du Louvre)

Aside from the coiffure, there is a further distinctive aspect of Hadrian's appearance which has recently been recognised and is often used as a diagnostic tool in the authentication of genuine ancient portraits of the fourteenth princeps. Hadrian possessed a deep, diagonal crease across both earlobes, a feature which has been identified as a possible marker of coronary artery disease and something which, as Thorsten Opper has observed, injects 'an unexpected dose of dramatic realism into his portrait'. ${ }^{45}$ Unfortunately, the earlobes of the Stonegate head have suffered greatly, being chiselled and planed back to the sides of the head, presumably in an attempt to make them appear less outsized and incongruous in the reworked portrait. In the course of this reshaping, the lobes have been largely removed.

\section{CONCLUSIONS}

It is clear that the Stonegate head is far more than it first appears, the larger than life image of a deified princeps being preserved beneath the recarved likeness of an early fourth-century imperial

45 Opper 2008, 59. 
candidate. The identity of the primary monumental statue is not conclusively proven, but is likely to have been Hadrian, being carved as a post-mortem likeness of the princeps during the reign of his successor, Antoninus Pius. As such, the head would represent the first image of Hadrian in stone to be identified from Britain, although a life-size bronze replica has been recorded from the river Thames, where it was dredged up in $1834 .{ }^{46}$ The full statue from York almost certainly stood close to where it was found, within the confines of the legionary fortress possibly, as first suggested by Richmond, ${ }^{47}$ inside the very headquarters building of VI Victrix. There is nothing from the new examination of the head to suggest that the secondary recarving of the image was not originally intended to represent the emperor Constantine I, in fact this aspect of the identification, first put forward in the 1940s, appears secure.

There is, however, one aspect of the Stonegate head that requires reconsideration, namely the date of the secondary recarving. It has always been assumed, perhaps understandably, that the image of Constantine was linked to his initial proclamation as Augustus by the soldiery of York following the demise of his father, the emperor Constantius, in A.D. 306. Indeed, Richmond noted that the head could 'take precedence in date among the known portrait heads' of Constantine, ${ }^{48}$ implying, without explicitly stating, that the replica was probably generated as part of Constantine's initial claim to the throne. This is an undeniably attractive theory, although it is, of course, ultimately unproven. Considering the portrait in detail, however, one aspect of the representation suggests that it was in fact created, not in the formative days of imperial power-grab, but some considerable time later.

In A.D. 306, when Constantine was raised to the position of emperor in York, imperial portraiture depicted the leaders of the State in a 'geometric and starkly abstract' style, eschewing all attempts to portray realism or personality. Rome was in the middle of a bold political experiment known as the tetrarchy in which the two emperors (of the Eastern and Western halves of the Empire), together with their nominated successors (or Caesars), were not represented as ordinary mortals but as part of an imperial collective or hive-mind. As a consequence, tetrarchic portraits played down certain aspects of the individual, instead depicting the four leaders of state with a 'blocklike geometry, a frozen, masklike expression and a military hairstyle and beard that seem to encase the head like a metal helmet' ${ }^{49}$ Constantius Chlorus, Constantine's father, was a tetrarch and, as such, was portrayed on coin with a thick neck, square head, short hair and stubble.

The earliest portraits of Constantine that survive, show him working within the established model of the tetrarch: 'a bearded blockhead' 50 indistinguishable from his starkly geometric colleagues. It was only after he had eliminated his rival Maxentius, at the Battle of the Milvian Bridge in A.D. 312, leaving the path to Rome uncontested, that we see a radical shift in imperial representation, Constantine transforming into an energetic and more youthful looking leader. Eschewing the beard and short, low-maintenance haircut, images of Constantine appeared with smooth cheeks and gently tousled coiffure, comma-shaped locks being arranged in an arc across the forehead. In this form of portraiture, his brows arch over intensely staring eyes; the nose is hooked; the jaw is firm and strong.

One feature of the Stonegate portrait can be used to help resolve the critical aspect surrounding the date of the recarving: namely the corona civica. The oak-leaf garland was a military decoration traditionally granted by the Senate to those who had saved the lives of fellow Roman citizens in battle. By bringing the civil war in Italy to an end, Constantine could, like Augustus before, claim

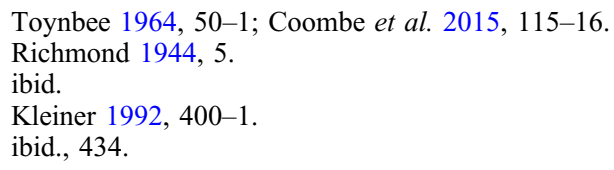


to have saved Roman lives, therefore earning him the right to wear the corona civica. ${ }^{51}$ This dress item became a defining feature of his later portraiture and its presence on the head of the Stonegate replica means that the image cannot have been created before A.D. 312. That year Constantine defeated Maxentius and took control of Rome, officially terminating the civil war, some six years after his acclamation by the soldiery of Britain.

There is a possible context for such a later piece of identity realignment, numismatic evidence suggesting that Constantine returned to Britain on two separate occasions following his departure in A.D. 306. Between A.D. 310 and 312, the London mint struck bronze issues with the inscription ADVENTVS AVG ('the coming of the emperor') set beneath an image of Constantine on horseback. Adventus coins would, as John Casey has convincingly argued, appear to have been issued when an emperor was present either in the mint-town or the immediate neighbourhood. ${ }^{52}$ A second Adventus type, minted in London between A.D. 313 and 317, seems to indicate a later return, plausibly coinciding with Constantine's adoption of the title Britannicus Maximus ${ }^{53}$ an appropriate time, perhaps, for a sculptor within the emperor's entourage to be modifying a marble statue in York.

The Stonegate portrait was not, therefore, a hastily conceived primary image of an early fourth-century officer who would later become emperor, but a representation of a successful emperor, created only after he had taken Rome, carved directly into the face of an earlier, deified princeps. Such an observation, of course, by no means diminishes the significance of the head, for few replicas of Constantine 'the Great' survive to this day. In fact, if anything, the importance of the Stonegate head, as a reworked monumental image of a second-century emperor, probably Hadrian himself, has increased significantly. This larger than life primary-phase statue was probably standing, its original identity intact, within the legionary headquarters building of Eboracum in A.D. 306, to be seen by Constantine at the very moment of his acclamation as emperor and his long march to destiny. Only later would it be remade in his likeness.

\section{ACKNOWLEDGEMENTS}

I am immensely grateful to the staff of Yorkshire Museum, especially curators Natalie McCaul and Adam Parker, for information surrounding the Stonegate head, to Carole Raddato for permission to reproduce images from her invaluable photographic archive and to the two anonymous referees for their helpful comments and advice.

Faculty of Science and Technology, Bournemouth University mrussell@bournemouth.ac.uk

BIBLIOGRAPHY

Alexandridis, A. 2004: Die Frauen des römischen Kaiserhauses: eine Untersuchung ihrer bildlichen Darstellung von Livia bis Iulia Domna, Mainz am Rhein

Bidwell, P. 2006: Roman Forts in Britain, London

Blanck, H. 1969: Wiederverwendung alter Statuen als Ehrendenkmäler bei Griechen und Römern, Köln Calomino, D. 2016: Defacing the Past: Damnation and Desecration in Ancient Rome, London

51 ibid., 437.

52 Casey 1978

53 ibid., 190-3; Merrifield 1983, 210. 
Casey, J. 1978: 'Constantine the Great in Britain - the evidence of the coinage of the London mint, AD 312314', in J. Bird, H. Chapman and J. Clark (eds), Collectanea Londiniensia: Studies in London Archaeology and History Presented to Ralph Merrifield, London, 181-93

Coombe, P., Grew, F., Hayward, K., and Henig, M. 2015: Corpus of Sculpture of the Roman World: Great Britain. Volume 1, Fascicule 10: Roman Sculpture from London and the South-East, Oxford

Evers, C. 1991: 'Propagande impériale et portraits officiels. Le type de l'adoption d'Antonine le Pieux', Mitteilungen des Deutschen Archäologischen Instituts, Römische Abteilung 98, 249-62

Galinsky, K. 2008: 'Recarved imperial portraits: nuances and wider contexts', Memoirs of the American Academy in Rome 53, 1-25

Harrison, E. 1967: 'The Constantinian portrait', Dumbarton Oaks Papers 21, 93-5

Hartley, E., Hawkes, J., Henig, M., and Mee, F. 2006: Constantine the Great: York's Roman Emperor, York

Henig, M. 1996: 'A royal portrait from Fishbourne, West Sussex', Journal of the British Archaeological Association 149, 83-6

Hiesinger, U. 1975: 'The portraits of Nero', American Journal of Archaeology 79, 113-24

Ireland, S. 2008: Roman Britain: A Sourcebook, London

Kinney, D. 1997: 'Spolia, damnation and renovatio memoria', Memoirs of the American Academy in Rome 42, 117-48

Kleiner, D. 1992: Roman Sculpture, Yale

L'Orange, H. 1933: Studien zur Geschichte des spätantiken Porträts, Oslo

Merrifield, R. 1983: London, City of the Romans, London

Opper, T. 2008: Hadrian: Empire and Conflict, London

Ottaway, P. 1993: Roman York, London

Prusac, M. 2011: From Face to Face: Recarving of Roman Portraits and the Late Antique Portrait Arts, Leiden

RCHME 1962: The City of York: Volume 1, London

Richmond, I. 1944: 'Three fragments of Roman official statues from York, Lincoln and Silchester', Antiquaries Journal 24, 1-9

Russell, M., and Manley, H. 2015: 'Trajan places: establishing identity and context for the Bosham and Hawkshaw heads', Britannia 29, 151-69

Soffe, G., and Henig, M. 1999: 'Roman marble and bronze sculpture in the kingdom of Togidubnus', Association for Roman Archaeology Bulletin 8, 8-10

Suetonius: 'Titus', The Lives of the Twelve Caesars, trans. J.C. Rolfe, Loeb Classical Library, Cambridge, MA/London (1914)

Toynbee, J. 1962: Art in Roman Britain, London

Toynbee, J. 1964: Art in Britain under the Romans, Oxford

Tufi, S. 1983: Corpus of Sculpture of the Roman World: Great Britain. Volume 1, Fascicule 3: Yorkshire, Oxford

Varner, E. 2004: Mutilation and Transformation: Damnatio Memoriae and Roman Imperial Portraiture, Leiden

Wrede, H. 1981: Consecratio in Formam Deorum, Mainz am Rhein

Wright, D. 1987: 'The true face of Constantine the Great', in W. Tronzo and I. Lavin (eds), Studies on Art and Archaeology in Honor of Ernst Kitzinger on his Seventy-fifth Birthday, Dumbarton Oaks Papers 41, 493-507 